\title{
Viral Heroism: What the Rhetoric of Heroes in the COVID-19 Pandemic Tells Us About Medicine and Professional Identity
}

\author{
Patrick D. Hopkins ${ }^{1,2}$ (D)
}

Accepted: 10 December 2020 / Published online: 7 February 2021

(c) The Author(s), under exclusive licence to Springer Nature B.V. part of Springer Nature 2021

\begin{abstract}
Throughout the COVID-19 pandemic the use of the term "hero" has been widespread. This is especially common in the context of healthcare workers and it is now unremarkable to see large banners on hospital exteriors that say "heroes work here". There is more to be gleaned from the rhetoric of heroism than just awareness of public appreciation, however. Calling physicians and nurses heroes for treating sick people indicates something about the concept of medicine and medical professionals. In this essay, I will examine three aspects of the social role of medicine exposed by the language of heroism. One, if a hero is someone who goes above and the call of duty, then does that mean exposing oneself to risk of infection is no longer a duty of physicians (as it used to be)? If so, does that mean the "profession" of medicine is much like any other business? Two, physicians and nurses are not the only "heroes" this go-around. Anyone deemed essential to the US "infrastructure" is designated by the US government as having "special responsibilities" to remain at their posts for the public good, which explicitly puts physicians in the same category as sewage workers and grocery store cashiers. Three, what does it mean to belong to a profession that does (or does not) have self-sacrifice and risk-taking as part of its missionespecially a profession that rarely gets called upon to practice these obligations?
\end{abstract}

Keywords Professional duties $\cdot$ COVID-19 $\cdot$ Pandemic $\cdot$ Heroism $\cdot$ Utilitarianism

\section{Introduction}

As I drive to work, I pass through the central medical district of my city, and indeed, the main medical district of my state. On this drive-along with thousands of other people coming from up to hundreds of miles away to see specialists, have

Patrick D. Hopkins

pdhopkins@umc.edu

1 Department of Psychiatry and Human Behavior and the Center for Bioethics and Medical Humanities, University of Mississippi Medical Center, Jackson, MS, USA

2 Department of Philosophy, Millsaps College, Jackson, MS, USA 
surgeries, get chemotherapy, visit hospitalized family and friends-we rely on signs to provide information. Signs tell us where the medical and nursing schools are, where to go for radiology or GI, when institutions were established, what religious affiliation this and that hospital has, what illness-of-the-week is being highlighted (National COPD Month!), and how excellent and well-ranked each institution is according to national surveys and rating systems. Since February of 2020, however, I and myriad other drivers are also told something else - that we are in the land of heroes. Billboards thank our heroes on behalf of companies and citizens. Large painted wooden signs stand on the grounds telling us that "Heroes Work Here". Huge banners stretching across entire 8-lane streets, attached to street-spanning walkways, announce "Heroes At Work". Inside a hospital, above the punch-in clock, is a cartoon taped to the wall of a person standing in medical scrubs looking at a set of papers named "COVID-19 response" and behind them is cast a shadow of a classic Superman silhouette with cape blowing in the wind.

So what is the nature of all this heroism? Apparently, hospitals and clinics are filled with heroes because the people working there are treating COVID-19 patients, or at least working around people who might be infected. Life in the time of COVID-19 has been uncertain, disruptive, and politicized, but in responding to the dangers and confusion by bravely treating the ill or working with the possibly infected, the message seems to be that healthcare workers have shown us the better angels of our nature. They demonstrate the best of ourselves at a time when so much of the worst of ourselves are also on display. For their actions, we are to be inspired and grateful.

There is more, however, to be gleaned from the rhetoric of heroism than just awareness of public appreciation or inspiration in a time of fear. Notice that lauding healthcare workers for treating the sick is lauding them for doing their jobor at least it seems to be. Isn't treating the sick, even the infectious sick, a part of medicine? Isn't it part of the profession? Or perhaps it isn't? Does calling physicians and nurses heroes for treating infectious sick people indicate some confusion in the role of healthcare providers, or perhaps some shift in the concept of what moral and social role medicine entails?

In this paper, I examine what the heroism rhetoric of the COVID-19 pandemic suggests about the social role of medicine. First, I look at the concept of the hero employed to get a clearer sense of what "hero" means and why it has appeared so strongly at this point. Second, I ask about two aspects of moral obligation related to providing healthcare during a pandemic and how these obligations have shifted and are perhaps shifting again. One, how much does the sense of "hero" employed in the COVID-19 pandemic indicate going above and beyond any professional obligation? Two, how does the new concept of infrastructure obligation, which applies to a wide variety of workers, including medical providers, water down the notion of a specifically professional duty? Third, I look at the notion of moral and professional identity, delineating ways in which empirical research suggests a traditional professionalism concept of hero may not be shared by the average lay person and how the self-identity of healthcare workers (particularly physicians) is affected by the situational rarity of medical heroism. 


\section{The Definitions of Medical Heroism}

As with many terms, "hero" can mean many different things. It is necessary to look at the specific context to determine what it means and especially to look at what it seems to be contrasted to. The term "hero" has been used to refer to a person notable for courageous acts, for nobility of character, for having special abilities, for having special achievements, for being a role model, for being chosen by destiny to accomplish great things, for being so famous as to be remembered for ages, for mythically exemplifying psychological development, and for simply being the protagonist of a story.

In the COVID-19 pandemic context, we can quickly rule out some of the more technical meanings of "hero" that we find in comparative literature and comparative mythology. The "heroes" that work in the hospitals are not timeless, not extremists in their personality traits, not antagonistic toward some supernatural agent (Nagy 2006). They do not follow a monomyth hero pattern of the sort outlined by Rank et al. (1990) or Raglan (1936) in which heroes are sons of kings, have their births prophesied, have a victory over a powerful enemy, take revenge on an enemy, and so on. Neither do they fit a Campbellian hero's journey model in which they receive a call, make a journey with supernatural aid, become semidivine, and return to enlighten their fellow citizens (Campbell 1949).

We can also rule out the more casual or unthinking uses of "hero" that largely refer to celebrity, cultural admiration, or role modeling. People often claim that influential relatives (fathers, grandmothers) are their personal heroes, or that accomplished sports figures, business successes, singers, or actors are their heroes, in some sort of aspirational model. While admiration is certainly part of what is going on with COVID heroism rhetoric, there seems to be little in the way of aspiring to be like these heroes as models of success.

What does seem crucial for being a pandemic hero is that healthcare workers who treat COVID patients or interact with those who might be infected are putting themselves at some risk in order to help others. It also appears, at first, that part of the perception of heroism is that it is not the obligation of these workers to put themselves at risk. They have not already agreed to take on this risk as part of their job and so are voluntarily going to work to help others. Their actions are supererogatory, above and beyond the formal call of duty. In this sense, what they are doing is both beneficial and not required of them.

There is an important caveat to this part of the definition. However, I will return to that later in the paper. For the moment, I will define the sense of "hero" used in COVID rhetoric to mean: a person who supererogatorily places themself at risk for contracting COVID-19 in order to help others. The term in this sense essentially marks someone as a kind of utilitarian saint or utility heroan unusually caring person who prioritizes others' happiness and suffering over their own individual happiness and suffering in order to achieve a greater good while under no formal requirement to do so. As a prominent early paper on the notion of heroes noted, physicians who take risks to treat people who are not already their patients are quintessential examples of supererogation: "A doctor in 
a plague-struck town has a duty to look after his patients, but a doctor who comes to help from the next province does not have a duty to do so. Both may be saintly or heroic, but only the second is so beyond the call of duty" (New 1974, p. 179; Urmson 1969).

If the sense of "hero" in use is the utilitarian hero, then we can ask how best to interpret this use and identify attendant social and moral issues. There are a number of tensions or conflicts that arise in thinking of physicians as heroes that can shed light on the nature of medicine as a profession and on the relationship to social beneficence.

\section{The Complications of Medical Heroism}

\section{Professional Obligations: Are Physicians Really Heroic?}

One issue is that this sense of heroism suggests that the hero is going above and beyond the call of duty. But are healthcare workers (I will often focus on physicians here, though other healthcare workers are often included) going beyond their duties or are they following established professional protocol? This issue was highlighted in a recent conversation I had with a military veteran. When asked how he was getting used to civilian life, one thing he remarked was that now, when boarding a plane and not wearing a uniform, he no longer got applause or thank-yous for his service. He said he was actually glad of that, because he always felt uncomfortable being thanked for something he had knowingly signed up for. To his way of thinking, the special attention he received was odd, because he had agreed to do what he was doing in exchange for money, education, and training.

So, is it true that COVID-19-treating physicians are doing supererogatory work? As a recognized, and indeed classic example of a profession, what are the professional obligations here?

Historically, the stated professional obligations of physicians in the United States have shifted back and forth. In the original 1847 American Medical Association Code of Ethics, the professional obligations of physicians explicitly included that during a "pestilence", physicians were duty-bound to alleviate suffering "even at the jeopardy of their own lives" (AMA 1847, p. 105). ${ }^{1}$ In 1900, in his presidential address to the AMA, William Keens said: "Be brave men. When pestilence stalks the streets and contagion lurks in every chamber of illness, where have the doctors

\footnotetext{
1 "ART. I.-Duties of the profession to the public. $\S 1$. As good citizens, it is the duty of physicians to be ever vigilant for the welfare of the community, and to bear their part in sustaining its institutions and burdens: they should also be ever ready to give counsel to the public in relation to matters especially appertaining to their profession, as on subjects of medical police, public hygiene, and legal medicine. It is their province to enlighten the public in regard to quarantine regulations,-the location, arrangement, and dietaries of hospitals, asylums, schools, prisons, and similar institutions, - in relation to the medical police of towns, as drainage, ventilation, \&c.,- - and in regard to measures for the prevention of epidemic and contagious diseases; and when pestilence prevails, it is their duty to face the danger, and to continue their labours for the alleviation of the suffering, even at the jeopardy of their own lives" (AMA., 1847, 105).
} 
been found? Fleeing from danger...? Nay... in the crowded tenements, in the hospitals ... cheerfully tending to the sick, facing the disease in the midst of its victims and seeking, even in the bodies of the dead knowledge that will make them masters of the plague.... [P] estilence has bred its many quiet heroes who have gone about their daily duty, simply, fearlessly, devotedly...." (Baker 2013, p. 309).

By 1912, the ethics code language was even stronger and more explicit (including wording about financial gain), stating "When an epidemic prevails, a physician must continue his labors for the alleviation of suffering people, without regard to the risk to his own health or to financial return" (Huber and Wynia 2004, w6; Baker et al. 1999).

This changed over time, however. By 1957, the Principles of Medical Ethics of the AMA had grown to 48 sections and 5,000 words and was becoming seen as unwieldy. The 1957 revision reversed course, dropping to 500 words and only 10 principles (Huber and Wynia 2004). Among the revisions was a much-weakened version of the plague duty: "A physician may choose whom he will serve. In an emergency, however, he should render service to the best of his ability" (Huber and Wynia 2004, w7). Eliminating the term "must" in favor of "should" and adding the vagueness of "best of his ability" is a far cry from being obligated to place one's own life in jeopardy.

Another transformation came in the 1980s, as a result of the political drama over HIV-AIDS. There was a great deal of uncertainty, moral tugs-of-war, and cultural turmoil, and physicians were disunited in whether they had an obligation to treat HIV + patients. The 1986 AMA statement that only physicians who were "emotionally able" to treat HIV + patients were obligated to was largely met with disdain (Freedman 1988; Huber and Wynia 2004) and only a year later the AMA replaced it with "A physician may not ethically refuse to treat a patient whose condition is within the physician's current realm of competence solely because the patient is [HIV] seropositive" (Huber and Wynia 2004, w8; Freedman 1988; Patterson 1989).

While this statement was specifically about HIV (and was informed by underlying issues about the specific moral and cultural context of HIV, including perceived homophobia), an epidemic had now reinforced the idea-and ethics policy-that physicians had a duty to treat. Much of this specific move was also informed by the claim that HIV was transmissible only by bodily fluids and thus relatively difficult to contract. Still, with the potential for needle sticks, the risk of contracting a virus was increased, and physicians were required to take that risk.

By the time of COVID-19, the AMA Ethics Code (as explicated in interpretive Opinion 8.3) had become more explicit about "disasters", stating: "Whether at the national, regional, or local level, responses to disasters require extensive involvement from physicians individually and collectively. Because of their commitment to care for the sick and injured, individual physicians have an obligation to provide urgent medical care during disasters. This obligation holds even in the face of greater than usual risks to physicians' own safety, health, or life. However, the physician workforce is not an unlimited resource. Therefore, when providing care in a disaster with its inherent dangers, physicians also have an obligation to evaluate the risks of providing care to individual patients versus the need to be available to provide care in the future" (AMA 2016). There is still wiggle room here that allows 
individual physicians to make decisions about how much to be involved in disaster situations (cast in utilitarian terms about future resources), but the statement that "physicians have an obligation" is nonetheless direct.

In comparison to the AMA, it is worth noting that the American Nurses Association's Code of Ethics for Nurses with Interpretive Statements, states that a nurse's primary commitment is to their patient (ANA Provision 2.1). However, Provision 5 states that nurses "owes the same duty to self as others, including the responsibility to promote health and safety" (ANA 2015, p. 35 online). Commenting on these competing claims, the ANA's specific statement on nurses, ethics, and the COVID19 pandemic says: "During pandemics, nurses and their colleagues must decide how much care they can provide to others while also taking care of themselves" (ANA 2020 , p. 2). There is no clear professional obligation to treat.

If it is the case that physicians, at least, have a professional obligation to treat COVID-19 patients even when doing so increases their own risks to "safety, health, or life", then are physicians being "heroic" in this work? As with the military veteran who said he had signed up for his job knowingly and did not think he should be called heroic, are physicians simply doing their duty? If it is their duty, then they would not be heroic for treating patients, any more than a police officer would be heroic for trying to stop a robbery (although a cashier who tried to stop the robbery could be heroic) or a firefighter would be heroic who carried people away from a fire (although a cashier who did so could be heroic). While people do tend to refer to police officers and firefighters doing their jobs as heroes, it is largely because such workers are regularly expected to place themselves at risk as part of the job and solike the perception of the military veteran-they are heroic simply for taking on that job in the first place. Physicians, however, do not regularly take on risks to health and life, even if their professional obligation is to do so during periods of disaster and epidemics.

There is a tension here, then, in that physicians do have a professional obligation to take on greater risks in the service of helping others but are rarely called upon to exercise that obligation. As a result, taking on such risks stands out as unusual even though it is supposed to be part of the job. In its principles and self-descriptions, the medical profession includes self-sacrifice and risk-taking similar to that required of police, military, and firefighters, but the profession is not typically seen as actually engaging those risks. Physicians treating COVID-19 patients is not supererogatory, but people do not know that it is not supererogatory. In fact, unlike police, firefighters, and military, the obligation to treat at greater risk to self may be so rarely called upon that physicians themselves are likely not as familiar with it (at least emotionally, if not intellectually). Most physicians likely have not internalized the obligation as part of their work.

This phenomenon was recently brought into sharp focus for me through incidents with medical students. Several situations have arisen in which medical students have specifically requested to be excused from clinical rotations and clinical training duties in order to avoid interaction with COVID-19 patients or other potentially infectious contacts. The assumption among the students seemed to be that any increased risk to themselves was simply unacceptable and that they had the right to avoid it. They seemed to have no awareness of what the AMA ethics principles 
required, or if they did, they did not take it seriously. In one particularly notable moment, during a focus group with students I was facilitating on improving clinical training, one student requested that my institution adopt a formal position that any student who refused to treat or be in potential contact with COVID-19 patients be protected from any consequences of disapproval or disapprobation from faculty. That is, not only did the student want to be able to avoid any contact with, and refuse to treat COVID-19 patients, but wanted formal assurances that this could not be held against them in terms of grades, attitudes, satisfying clinical requirements, or future recommendation letters. Let me be clear, these are just a few anecdotes and should in no way be generalized to the population of medical students at any institution or at large, but it is a stark reminder of how some people see their own profession (if they see it as a traditional profession at all).

The point in all this is not that physicians should not be called heroes or that physicians and medical students should be on board with the duties espoused by the AMA. The question of what physicians' obligations should be is a distinct issue that has been discussed extensively. What I am pointing out here is that medicine is in a bit of a complicated situation with regard to how it is perceived both internally and externally. Internally, the medical profession describes itself as a self-sacrificing, risk-taking, socially responsible enterprise with duties like that of other risk-taking professions, but the situations in which practitioners are called upon to fulfill these duties are rare-so much so that when they do occur, profession members themselves do not take it for granted that they are obligated to put themselves at risk for the social good (surely no police or firefighting or military trainee would think they could be excused from risky assignments). Externally, the medical profession is generally not seen as risky, as heroic, as self-sacrificing, so physicians who do treat patients during pandemics seem unusual and worthy of praise. Add to this the fact that physicians make salaries much higher than the national average (and especially higher than police, firefighters, and military) and since they rarely face risky situations, their working with COVID-19 patients comes across less like a professional responsibility and more like, at best, noblesse oblige.

Somewhat ironically then, physicians who treat pandemic patients are seen as heroic because what they are doing does not seem like part of what it means to be a physician at all. The profession wants to maintain a sense of socially responsible nobility about itself, but at the same time, wants to highlight its self-required actions as unusually noble. The signs and banners adorning the hospitals could say "We Aren't Heroes. This Is Just What Doctors Do". But that is not what they say.

\section{Infrastructure Obligations: Are Physicians Heroic in the Same Way Janitors are Heroic?}

There is another interesting tension in the rhetoric of heroic physicians and other healthcare workers. It may be that they are perceived and promoted as being heroic far less because they are members of a noble profession, than simply because they are useful. Healthcare workers are not the only people described as heroic during the COVID-19 pandemic. Anyone who puts themselves at increased risk of infection by 
virtue of their work has also been lauded. That includes janitors, food service workers, cashiers, and farmers. These are people who provide important services either directly for COVID-19 patients (e.g., janitors who sanitize and clean hospitals and nursing homes in order to decrease the spread of the virus) or indirectly through keeping supply channels going and having to socially interact at an increased-risk rate.

Public service announcements thank food service workers. Grocery stores thank their heroic employees because the cashiers are necessary to sell food and sanitizers. Pharmacies display posters suggesting customers thank the pharmacy technicians who are working to provide them medicine. Commercials for cleaning products and cleaning services thank the custodial workers who are selflessly striving to keep our buildings sanitized. Sometimes these workers are pointed to as "unsung heroes" because physicians and nurses get more attention, but it is not uncommon to see a wide range of extolments. The banner that says "Heroes Work Here" does not just hang across the nearby hospital street walkway. It also literally hangs above the first major aisle in my local hardware and home improvement megastore.

It might seem that all these non-healthcare workers are particularly deserving of the hero moniker since they do not belong to a classic profession with established social roles, codes of ethics, and long-standing, organized forms of special training. They may belong to unions or associations, but for the most part, they do not belong to the guild-like professions. Since these workers have no professional duty to serve the public at higher risk to themselves, they may appear to be individuals with heightened sense of charity and decency - truly supererogatory.

However, that view is complicated by another phenomenon. Perhaps these workers are not, in fact, going above and beyond the call of duty either. Their duties come not from their membership in a profession, but from their membership in organized society and their particular labor roles (albeit labor roles that may have been chosen primarily by the sheer need to earn a living). The contemporary language for this is that such people are "essential workers" in the "critical infrastructure" of the country.

The language of essential and critical is widespread, but the best summary of it comes from the Cybersecurity and Infrastructure Security Agency (CISA) of the U.S. Department of Homeland Security. CISA is the risk management and advising agency created by the Cybersecurity and Infrastructure Security Agency Act of 2018 (Congress 2020). A stand-alone agency within Homeland Security, its goal is "working with partners to defend against today's threats and collaborating to build more secure and resilient infrastructure for the future"(CISA 2020a).

CISA issued a formal guidance memorandum on the essential critical infrastructure workforce on March 19, 2020 and has followed up with three revisions-the most recent issued on August 18, 2020. The goal of those memoranda is to help state and local officials determine what workers are, in fact, essential for the critical infrastructure of the U.S. and provides lists of roles and positions that must be staffed in order to keep the country functioning. The memoranda make it clear that it is advisory in nature and is not a federal directive (CISA 2020). However, the memoranda are also very clear that some people have special obligations during a pandemic, based on what types of work they do. Version 1.0 of the advisory states: "If you 
work in a critical infrastructure industry, as defined by the Department of Homeland Security, such as healthcare services and pharmaceutical and food supply, you have a special responsibility to maintain your normal work schedule" (CISA 2020b). Version 2.0 states: "Functioning critical infrastructure is imperative during the response to the COVID-19 emergency for both public health and safety as well as community well-being. Certain critical infrastructure industries have a special responsibility in these times to continue operations" (CISA 2020c). Every version has some variation of these statements, emphasizing a "special" responsibility (CISA 2020e).

The lists of workers who have these special responsibilities during a pandemic infrastructure threat include categories of work, such as "medical and healthcare, telecommunications, information technology systems, defense, food and agriculture, transportation and logistics, energy, water and wastewater, law enforcement, and public works" (CISA 2020d). The documents go on to categorize industries deemed critical. As expected, Healthcare and Public Health is the first category, followed by (among others) Law Enforcement, Food and Agriculture, Waste and Wastewater, Public Works, Hazardous Materials, Finance, and Hygiene Products.

It is obvious how these (and the other unmentioned) industries fit the characteristic of "essential" and "critical". But what is interesting for purposes of this paper, is that physicians and other healthcare workers are classified as having special duties to engage in tasks that heighten their COVID-19 risks for the same reason grocery store cashiers and sewage plant workers are-they are necessary elements of the infrastructure machinery. Physicians, nurses, and other healthcare workers are explicitly included right along with restaurant carry-out and food delivery drivers, grain and oilseed handlers, animal feed packagers, cafeteria workers, sawmill operators, coal miners, vegetation management traffic controllers, propane gas call center operators, sewer repair-people, bus drivers, last-mile postal carriers, repair service dispatchers, ATM repair workers, housing inspectors, and laundromat operators. This may seem like it simply includes everyone, and it is quite expansive, but it does not include everyone. Among the traditional professions, teachers, lawyers, and clergy at not mentioned in the first version of the advisory (though they partly show up later). Florists, artists, furniture salespeople, cosmeticians, clothing designers, entertainers, personal trainers, dry cleaners, journal editors, historians, and ethicists never show up.

Additionally, within the specific identified category of healthcare and public health, along with physicians, nurses, phlebotomists, and radiology technicians are included gravediggers and coffin-makers - a stark reminder of what becomes critical during a pandemic and how public health depends on how we manage the dead as well as the living.

The point here is not that it should be humbling or bracing to physicians that they are included among cashiers and lettuce-packers as having special duties-though that may be of use in some cases (statistically, a few absent wastewater managers might lead to more disease-related deaths than a few absent physicians). Rather, the point is that most of these people did not sign up or join any profession that told them ahead of time they would have special duties to place themselves at higher risk during a pandemic situation. They have these duties (if they do) because of what 
happens to be important during a particular type of disaster, and that would change depending on the situation.

\section{The Implications of Medical Heroism}

We have arrived at a surprising place. While at first it seemed that physicians were described as heroic because they were doing something especially good, it turns out that they are simply doing what they are supposed to do professionally. Even if there were no professional duties, or if the next AMA ethics code drops such obligations, physicians will still be seen as having special responsibilities by virtue of their utility in national infrastructure, along with a large number of other workers. That infrastructure framework also suggests that no one acts supererogatorily if the work they do is needed. The florist, the personal trainer, and the journal editor would be going beyond their duties if they were to volunteer to work with COVID-19 patients, but only because their specific skills were not needed. In the infrastructure obligation framework, it is need itself that determines responsibilities. So, in one way or another, the healthcare-heroes being praised are not heroes in the sense of going beyond their duty.

So why are they called heroes and what does that suggest about the perception of the role of medical practitioners in society? There are two areas to look at here-the moral identity of medical workers as revealed during a pandemic (how is their moral role perceived, how are their moral obligations perceived, how is their moral character perceived?) and the self-identity of medical workers (how do they see themselves, what does the hero appellation mean to them?).

\section{The Moral Identity of Medical Practitioners as Heroes}

It may be that the perception of heroism has less to do with whether someone is doing their duty or not, whether someone has a professional obligation or not, or whether someone is essential or not, than it first seemed.

When I first began sorting through the possible meanings of "hero" in this context, I conceptualized this type of hero as a "utilitarian saint". What I meant by that was that a contemporary moral hero (contrasted with literary, archetypal, classic, and celebrity types of heroes) is someone who puts themselves at risk, or at least prioritizes others' benefits over their own, and does this for as many people as they can when it is not already their obligation to do so-which is an unusual thing to do. The key elements seemed to be the unusual act of supererogatorily helping others at risk to oneself. While this is a strong definition of a hero, research suggests that supererogation is not that significant.

The empirical research on the psychology of heroism is relatively new (Franco et al. 2016; Frimer and Sinclair 2016; Kinsella 2015a, b; Allison and Goethals 2011, 2013, 2014; Allison et al. 2017). While heroes have long been a subject of literary research, the moral psychology and social perception of heroism is just beginning to get systematic attention. A number of studies have sought to outline the perceived 
central traits of heroes (Kinsella 2015a) and relate them to perceptions of leaders and celebrities (they do not match up well). For my purposes here, though, one study in particular may shed some light on the relationship between professional or infrastructure obligations and the appellation of "hero".

A very interesting set of studies by Kraft-Todd and Rand (2019) points out that there is a consensus assumption among researchers that the elements associated with heroes are the risk the agent takes, the good the agent does, how common the action is, and whether the agent is expected or required to perform the action. This is consistent with the early analysis in this paper of a kind of utilitarian saint. However, Kraft-Todd and Rand decided to study how each of these four elements associated with heroism influenced lay intuitions and assessments about what specific acts were heroic.

They first generated a set of actions that ranged from ranking high in heroism to ranking low (there were no "villainous" behaviors, only behaviors that, although good, were not perceived as "heroic"). A sample of the 80 behaviors studied included: a child standing up for another child being bullied, a dog fighting off a wild animal to save his or her owner, a person helping their wife deliver their child, a person jumping on a grenade to save fellow soldiers, a person shielding someone during a shooting, admitting mistakes, adopting an animal (Kraft-Todd and Rand 2019). Jumping on a grenade was ranked as highly exemplary of heroism, while admitting a mistake was ranked as low or only ambiguously "heroic". Then they had subjects rank 5 highly rated behaviors and 5 low rated behaviors on each of the four elements associated with heroism by researchers, which they described as: "descriptive normativity ("In your opinion, how many people in your community do this behavior?"), injunctive normativity ("In your opinion, how much do people in your community think doing this behavior is what you are supposed to do?"), benefit to the recipient ("In your opinion, how much benefit (in terms of money, time, effort, etc.) does the recipient of this behavior receive?"), and cost to the actor ("In your opinion, how much cost (in terms of money, time, effort, etc.) does the person who does this behavior incur?")" (Kraft-Todd and Rand 2019, p. 4).

What they found was that only two of the four elements turned out to be significantly associated with the assessment of heroism. Descriptive normativity (how common is this?) was strongly associated with heroism, as was the cost to the agent. However, injunctive normativity (was there an obligation to do this?) was not associated with heroism, nor was the amount of good produced for the recipients. ${ }^{2}$

\footnotetext{
${ }^{2}$ This is not to say that utility is of no concern. Utility-the concept of a benefit to someone else-is a necessary part of what makes the hero's actions admirable. Simply placing themselves at risk is not sufficient. To be a hero, the risk one takes needs to be in the service of doing some genuine good (even if the amount of good is not key). John Stuart Mill himself made this point when defending utilitarianism against criticisms that humans often do without happiness and seek to develop virtue more than acquire happiness. Mill stated: “...but, after all, this self-sacrifice must be for some end; it is not its own end; and if we are told that its end is not happiness, but virtue, which is better than happiness, I ask, would the sacrifice be made if the hero or martyr did not believe that it would earn for others immunity from similar sacrifices? Would it be made if he thought that his renunciation of happiness for himself would produce no fruit for any of his fellow creatures, but to make their lot like his, and place them also in the condition of persons who have renounced happiness? All honour to those who can abnegate for themselves the personal enjoyment of life, when by such renunciation they contribute worthily to increase the amount of happiness in the world; but he who does it, or professes to do it, for any other purpose, is
} 
Kraft-Todd and Rand describe both of these findings as surprising-especially the finding on the insignificance of injunctive normativity: "Our finding that judgments of heroism are linked to the descriptive normativity of the action but not the injunctive normativity was also surprising to us, as our intuition was that 'going above and beyond' was an important part of being seen as heroic. Our data indicate, however, that this is not the case. Many of the proposed acts of heroism in Study 1 included professions where taking risks to help others is part of the job expectations (e.g. military, firefighter...). Thus, for these people acting heroically may not be unexpected (i.e. is injunctively normative), but it still may be rare (i.e. is descriptively non-normative). The fact that such actions were still judged to be heroic indicates that unexpectedness (or injunctive normativity) does not appear to be a crucial component of lay perceptions of heroism" (Kraft-Todd and Rand 2019, p. 6).

While this study has its limits (based on an mTurk convenience sample), it nonetheless provides some potential insights into the medical heroism issue. Physicians and janitors (and florists, if they were volunteering) are all described as heroes and it does not seem to matter for purposes of that ascription whether the workers are obligated (by professional standards or social need) or not. What matters is that it is uncommon and that it is increases self-risk. This makes the assessment of heroism be largely about having an unusual character that leads to unusual behavior-not about duties and not about the amount of good done, having more to do with virtue than either duty or utility.

\section{The Self-Identity of Medical Practitioners as Heroes}

If this is about how other people define heroes - the moral and social identity of heroes-what about self-identity? How do healthcare workers think of themselves and how should they think of themselves? It is very unusual for individuals to describe themselves as a hero. In fact, we seem to think it incumbent upon a true hero not to describe themselves as heroes, which is consistent with research showing it is about the perceived character of the agent that makes them a hero much more than the amount of good that they do.

So when a person being praised as a hero says they are not a hero, they may simply be showing humility, or they may simply be pointing out that in their profession they are expected to do this job, or they may be emphasizing that they "signed up" for this. In any case, if they were to say "yes, you're right, I am a hero", it would strike most people as arrogant and odd-even the people who lauded them for being heroes. It is a quirky aspect of human moral psychology that we often require an ironic protestation of a moral judgment in order for the recipient to deserve the moral judgment. ${ }^{3}$

\footnotetext{
Footnote 2 (continued)

no more deserving of admiration than the ascetic mounted on his pillar. He may be an inspiring proof of what men can do, but assuredly not an example of what they should" (Mill, 2001, 16).

3 Imagine how it would sound if you told a friend whose spouse had committed suicide "It's not your fault" and they replied "I know it's not my fault. It was his decision." Even though you may believe it is
} 
There is another sense, however, in which someone could reject the appellation of "hero". They may consider being a "hero" a consolation prize, or a distraction, or a substitution for something more valuable or substantive. In her demand for effective personal protective equipment, nurse activist Bonnie Castillo finds being called a hero a pale substitute for meaningful support for what nurses do. She considers being called a hero, being praised, or given token honors, as a way leaders avoid the serious and more difficult work of actually improving pandemic situations. She writes:

But this year, the International Year of the Nurse and Midwife, we cannot emphasize enough that praise is empty-even insulting-without protections. [...] Nurses are used to our employers giving us infuriating and demeaning gifts on Nurses' Week. They do it every year, while they fail to protect us all year long. It's 2020, nurses are literally fighting for their lives during this pandemic, and we have had enough. It's time for hospitals and our society to value the care work that upholds life, rather than the profits gleaned from human suffering. (Castillo 2020)

A similar point was made by a nurse who brought a sign to a protest that read "Please don't call me a hero. I am being martyred against my will. Defense Production Act now!" (Palus 2020). Lauding someone as a hero may be a genuine assessment, but can feel like cold comfort for those who are trying to accomplish good at risk to themselves.

\section{Conclusion}

There is a great deal more that could be said and more to be researched in this area (e.g., a hero who refuses to be called a hero will still come to resent not being appreciated if they are not thanked or lauded). But for my purposes here it is enough to remark that even while individuals may not think of themselves as heroes, and may come across as odd or arrogant if they did, there is still something to be said for belonging to a profession that collectively promotes (or requires) heroic acts (in the reduced sense of unusual risk-taking to help others). There is something bracing, but also inspiring about joining a group that says we are so committed to the social good that we will put ourselves in harm's way to help our fellow citizens.

While no individual physician would be admired for saying they are a hero, there is something felt to be ennobling about being a member of profession that imposes on itself this high level of moral obligation. Part of what makes a person feel they are joining something special is that they have a code of ethics (which most jobs do not) and that they have a storied tradition of risk-taking for the social good (which

Footnote 3 (continued)

not your friend's fault and you are trying to comfort them, you still seem to expect them to feel guilt even though you try to talk them out of it. 
most jobs do not). Think of how different it would sound if William Keen, in his 1900 address, had said: "When pestilence stalks the streets and contagion lurks in every chamber of illness, where have the doctors, and the janitors, and the food service workers, and the wastewater managers been found? Fleeing from danger...? Nay... in the crowded tenements, in the hospitals ... facing the disease in the midst of its victims...." Does hearing it put this way seem to diminish the sense that being a physician is something special?

The problem with medicine is that even if that commitment feels good and looks good on paper, situations in which the commitment has to be realized are relatively rare-unlike situations for military, firefighters, and police officers, for whom risktaking is much more common. So, for medicine, the commitment is more idealistic than concrete. When a pandemic does occur and some physicians or medical students suddenly balk at treating the sick for self-interested reasons, those members of the profession who admire the noble aspirations and codified sentiments of the AMA are disappointed that people going into medicine can have such a diminished view of their duties. Thus, medicine, much more than firefighting, policing, or military service, has a conflicted relationship with the self-identity of heroism. For many, it may be important to join a group that has lofty and heroic (unusual levels of risk-taking for a greater good) moral goals, but without regularly-occurring situations that require living up to those goals, it is easy for them to be pro forma more than substantive-in a way similar to how no-fault divorce practically reduces the "vow" to "have and to hold, from this day forward, for better, for worse, for richer, for poorer, in sickness and in health, to love and to cherish, till death do us part" to an aspirational, sentimental gesture rather than a genuine obligation.

So, does medicine or nursing or respiratory therapy want to be a profession that requires of its members increased risk to self during medical emergencies? Do members want to belong to a group that self-identifies as a profession with heroic obligations? Do members want the ennobling, distinguishing, social unity benefits that come with membership in such a group (like being a soldier)? If so, then these professions should own their obligations and explicitly state to the new generation of students coming up that they will in fact be expected to serve at risk to themselves during a pandemic. If not, well, chances are the service outcome will be much the same, not as a professional obligation but as a social utility obligation.

Author Contributions Not applicable.

Funding None.

Data Availability Not applicable.

Code Availability Not applicable.

\section{Compliance with Ethical Standards}

Conflict of interest None. 


\section{References}

Allison, S. T., \& Goethals, G. R. (2011). Heroes: What they do and why we need them. New York: Oxford University Press.

Allison, S. T., \& Goethals, G. R. (2013). Heroic leadership: An influence taxonomy of 100 exceptional individuals. New York: Routledge.

Allison, S. T., \& Goethals, G. R. (2014). "Now he belongs to the ages": The heroic leadership dynamic and deep narratives of greatness. New York: Palgrave Macmillan.

Allison, S. T., Goethals, G. R., \& Kramer, R. (Eds.). (2017). The handbook of heroism and heroic leadership. New York: Routledge.

AMA. (1847). Code of medical ethics of the American Medical Association. Chicago. American Medical Association Press. https://www.ama-assn.org/sites/ama-assn.org/files/corp/media-browser/publi c/ethics/1847code_0.pdf Accessed 23 Sept 2020.

AMA. (2016). Physicians' responsibilities in disaster response \& preparedness, Code of Medical Ethics Opinion 8.3. https://www.ama-assn.org/delivering-care/ethics/physicians-responsibilities-disasterresponse-preparedness. Accessed 13 Sept 2020.

ANA (American Nurses Association) (2015). Code of ethics for nurses with interpretive statements. https ://www.nursingworld.org/coe-view-only. Accessed 13 Sept 2020.

ANA (American Nurses Association). (2020). Nurses, ethics and the response to the COVID-19 pandemic. https://www.nursingworld.org/ 4981cc/globalassets/covid19/nurses-ethics-and-the-respo nse-to-the-covid-19-pandemic_pdf-1.pdf. Accessed 13 Sept 2020.

Baker, R. B., Caplan, A. L., Emanuel, L. L., \& Latham, S. R. (1999). The American medical ethics revolution. Baltimore: Johns Hopkins University Press.

Baker, R. (2013). Before bioethics: A history of American medical ethics from the Colonial period to the bioethics revolution. New York: Oxford University Press.

Campbell, J. (2004) [1949]. The hero with a thousand faces. Princeton: Princeton University Press.

Castillo, B. (2020). This Nurses' Week, don't call us heroes. Call for safe COVID-19 protections. Medium. https://medium.com/@NNUBonnie/this-nurses-week-don-t-call-us-heroes-call-for-safecovid-19-protections-64c4c168cf68. Accessed 13 Sept 2020.

CISA. (2020a). About CISA. https://www.cisa.gov/about-cisa. Accessed 13 Sept 2020.

CISA. (2020b, March 19). Memorandum on identification of essential critical infrastructure workers during Covid-19 response. https:/www.cisa.gov/sites/default/files/publications/CISA-Guidance-onEssential-Critical-Infrastructure-Workers-1-20-508c.pdf. Accessed 13 Sept 2020.

CISA. (2020c, March 28). Advisory memorandum on identification of essential critical infrastructure workers during Covid-19 response. https:/www.cisa.gov/sites/default/files/publications/CISA_ Guidance_on_the_Essential_Critical_Infrastructure_Workforce_Version_2.0_1.pdf. Accessed 13 Sept 2020.

CISA. (2020d, April 17). Advisory memorandum on identification of essential critical infrastructure workers during Covid-19 response. https://www.cisa.gov/sites/default/files/publications/Versi on_3.0_CISA_Guidance_on_Essential_Critical_Infrastructure_Workers_3.pdf. Accessed 13 Sept 2020.

CISA. (2020e, August 18). Advisory memorandum on ensuring essential critical infrastructure workers ability to work during the Covid-19 response. https://www.cisa.gov/sites/default/files/publications/ Version_4.0_CISA_Guidance_on_Essential_Critical_Infrastructure_Workers_FINAL\%20AUG \%2018v3.pdf. Accessed 13 Sept 2020.

Franco, Z., Allison, S. T., Kinsella, E. L., Kohen, A., Landgdon, M., \& Zimbardo, P. G. (2016). Heroism research: A review of theories, methods, challenges, and trends. Journal of Humanistic Psychology, 58(4), 382-396.

Freedman, B. (1988). Health professions, codes, and the right to refuse to treat HIV-infectious patients. The Hastings Center Report (April-May), 18(2): S20-S25. https://doi.org/10.2307/3562422.

Frimer, J. A., \& Sinclair, L. (2016). Moral heroes look up and to the right. Personality and Social Psychology Bulletin, 42(3), 400-410.

Huber, S. J., \& Wynia, M. K. (2004). When pestilence prevails: Physician responsibilities in epidemics. The American Journal of Bioethics, 4(1), W5-W11.

Kinsella, E. L., Ritchie, T. D., \& Igou, E. R. (2015). Zeroing in on heroes: A prototype analysis of hero features. Journal of Personality and Social Psychology, 108, 114-127. 
Kinsella, E. L., Ritchie, T. D., \& Igou, E. R. (2015). Lay perspectives on the social and psychological function of heroes. Frontiers in Psychology, 6, 1-12.

Kraft-Todd, G. T., \& Rand, D. G. (2019). Rare and costly prosocial behaviors are perceived as heroic. Frontiers in Psychology, 10, 234. https://doi.org/10.3389/fpsyg.2019.00234.

Mill, J. S. (2001). Utilitarianism (2nd ed.). Indianapolis/Cambridge: Hackett Publishing.

Nagy, G. (2006). The epic hero, 2nd ed. Center for Hellenic Studies. Washington, DC. http://chs.harva rd.edu/publications/. The 1st ed. (printed version) of The epic hero appeared in Foley, J.M. (Ed.) (2005). A companion to ancient epics (71-89). New York: Oxford University Press.

New, C. (1974). Saints, heroes and utilitarians. Philosophy, 49(188), 179-189.

Palus, S. (2020). A nurse explains who can call her a hero and what she thinks of all the applause. Slate. https://slate.com/technology/2020/04/nurse-hero-protest.html. Accessed 13 Sept 2020.

Patterson, R. (1989). AIDS: The duty to treat. Mt. Sinai Journal of Medicine, 56(3), 250-251.

Raglan, L. R. (1936). The hero: A study in tradition, myth and drama. New York: Dover Publications.

Rank, O., Raglan, L., \& Dundes, A. (1990). In quest of the hero. Princeton: Princeton University Press.

Urmson, J. O. (1969). Saints and heroes. In J. Feinberg (Ed.), Moral concepts (60-73). Oxford: Oxford University Press.

U.S. Congress. (2017-2018). H.R.3359-115th Congress. https://www.congress.gov/bill/115th-congress/ house-bill/3359. Accessed 13 September 2020.

Publisher's Note Springer Nature remains neutral with regard to jurisdictional claims in published maps and institutional affiliations. 